\title{
OS NOVOS PROLETÁRIOS DO MUNDO NA VIRADA DO SÉCULO'
}

\author{
José Flávio Bertero \\ Docente do Departamento de Ciências Sociais da \\ Universidade Estadual de Londrina
}

omento nestas notas aspectos do livro supra referido. Tomo como ponto de partida e ao mesmo tempo fio condutor de minhas reflexões o apêndice II e o capítulo VI do citado livro.

O autor considera o tema acima aludido muito sugestivo " (...) para entender a nova conformação do mundo do trabalho, dos novos proletários do mundo"(p.195). Diz pensar "que talvez possa, nesta discussão, levantar um conjunto de questões, para ao menos indicar o que são os trabalhadores do mundo no final do século XX". Certamente "não são idênticos ao proletariado de meados do século XIX". "Mas (...) também não estão em vias de desaparecimento, quando se olha o mundo em sua dimensão global" (p.195).

Propõe-se, portanto, compreender (e explicar, acrescento eu: JFB) o proletariado ou "a classe - que - vive - do - trabalho", "a classe que vive da venda da força de trabalho", nesse final de século. Alega não se tratar de um conceito novo e sim de uma "tentativa de caracterizar a ampliação do proletariado...", a fim de melhor entendê-lo (p.196), uma vez que ele não mais se restringe aos trabalhadores industriais, mas, ao contrário, estende-se ao conjunto dos assalariados que compõem a classe trabalhadora (p.196).

O seu referencial teórico é Marx, que muitas vezes, segundo ele, definiu a classe trabalhadora como proletária. Não só Marx, aliás, senão também Engels. Ambos empregaram como sinônimos os conceitos de "trabalhadores e de proletários"'(p.196). Acredita ser essa definição

\footnotetext{
' Resenha da obra de ANTUNES, Ricardo. Os sentidos do trabalho. São Paulo: Boitempo Editorial, 1999.
} 
"marxiana e marxista" "inteiramente pertinente" para se pensar a classe trabalhadora hoje (p.196).

Ao fazer tal afirmação, Ricardo Antunes cita indistintamente textos vários de Marx e Engels, tais como: o Manifesto Comunista, $O$ Capital. Sabe-se, entretanto, que o Manifesto, malgrado a sua riqueza e atualidade, é de 1847/48, ocasião em que seus autores ainda não possuíam o conceito de força de trabalho. A falta deste conceito os impedia de explicar cientificamente a extração do excedente do trabalho no capitalismo, a chamada mais-valia. O que só acontecerá anos mais tarde, em 1857/58. Em 1847/48, época da redação de o Manifesto, os seus autores não tinham, em consequiência, um conceito preciso de proletariado, nem de capital e menos ainda de capitalismo, os quais não se encontravam devidamente elaborados. Em o Manifesto, esses conceitos padecem de imprecisões, sobretudo se tem em conta os estudos posteriores desses autores, especialmente $O$ Capital.

Interessa-me, neste momento, o conceito de proletário exposto nessa obra maior de Marx (1984, p.714). A saber: por "proletário deve entender-se economicamente o assalariado que produz e expande o capital e é lançado à rua logo que se torna supérfluo às necessidades de expansão do 'monsieur capital', como o chamava Pecqueur".

Se bem entendo, implícita a esse conceito está a idéia conforme a qual nem todo assalariado é proletário. Pois, para que o assalariado seja proletário, é preciso que o seu trabalho esteja a serviço do capital e que seja produtivo, isto é, que ele seja capaz de gerar mais-valia. O que quer dizer que o seu trabalho pertence ao trabalho social, trabalho este indiferenciado, abstrato, do qual é expressão concreta e sem o qual não mais opera. É isso, fundamentalmente isso, que determina a sua situação de classe, conferindo-lhe, ademais, identidade (MARX, 1984; 1978; FAUSTO, 1987; OLIVEIRA, 1987).

Retomo, contudo, a exposição de Ricardo. O seu desafio é entender "o que é a classe trabalhadora hoje" (p.196), "o que é o proletariado hoje". O proletariado ou a classe trabalhadora hoje ou - o que para ele é a mesma coisa - "a classe - que - vive- do- trabalho hoje". Ela ou ele, como queiram, "compreende a totalidade dos assalariados, homens e mulheres que vivem da venda da sua força de trabalho e que são despossuídos dos meios de produção" (p.196). 
Ricardo acerta, segundo penso, quando afirma que a classe trabalhadora não se limita aos trabalhadores manuais ou ao proletariado industrial. Engana-se, entretanto, ao identificá-la com o trabalhador coletivo. A classe trabalhadora é mais ampla que o contingente dos trabalhadores produtivos que formam o trabalho coletivo. Não fora assim, haveria coincidência entre assalariados e proletários. Ocorre que nem todo assalariado é proletário. A fim de melhor elucidar essa questão cito, a título de exemplo, o caso do professor de uma instituição pública de ensino: ele é assalariado, mas não é proletário. Tal fato dá uma abrangência maior ao assalariado em relação ao proletariado, que, a meu ver, pode e deve ser identificado com o trabalhador coletivo. É a massa proletária que constitui a crescente capacidade de trabalho socialmente combinada que realiza a produção social. Integram-na trabalhadores diversos que cooperam entre si, mas que participam de maneira diferente do processo produtivo, posto que uns trabalham manualmente, outros intelectualmente, uns como diretor, gerente, engenheiro, técnico, etc; outros como encarregado, chefe de seção; outros como simples operário ou ajudante. Isso significa que mais e mais trabalhos concretos componentes desse organismo social, que é o trabalhador coletivo, se incluem no conceito de trabalho produtivo e, logicamente, no conceito de proletário, se tem em conta a definição de proletário de Marx da maturidade. A rigor, essa massa de trabalho coletivo é posta pelo capital com vistas à sua auto-valorização.

Salvo equívoco, não há como identificar classe trabalhadora e proletário ou trabalhador produtivo. Ela não é, conforme quer Ricardo, centralmente composta por trabalhadores produtivos (p.196-197). No entanto, ele acerta de novo quando diz que o trabalho produtivo é o núcleo do proletariado moderno (p.196). O problema está no seus conceitos de classe trabalhadora e de proletariado, no entendimento que tem dessas categorias sociais. Mais ainda: observa que o trabalho que cria mais-valia, e assim contribui para a valorização do capital, é o trabalho abstrato. Corretíssimo. Persiste, todavia, a confusão entre trabalhador produtivo e classe trabalhadora (p.197). Bem como surge uma nova confusão: a concernente à relação entre trabalho vivo e trabalho abstrato, que, no meu entender, não se eqüivalem. O raciocínio aqui é o mesmo do usado anteriormente, ou seja, ainda que todo trabalho abstrato seja 
trabalho vivo, nem todo trabalho vivo é abstrato. E é este trabalho e não aquele que produz valor. Para usar um exemplo dado pelo próprio Ricardo: nem todo serviço é produtivo, embora todo serviço pressuponha o trabalho vivo. Ao que é mister acrescentar que trabalho abstrato não se resume no "dispêndio de energia física e intelectual", como acentua Ricardo. Marx não se limita a isso em $O$ Capital. Basta ler a seção da mais-valia relativa para constatar esse fato. Portanto, mesmo que cite Marx, Ricardo não o faz devidamente, razão por que polemiza mal (p.197). Depreende-se da leitura da aludida seção que é a máquina e o mecanismo que ela origina, o sistema de máquinas, que produzem o trabalho abstrato. O trabalho abstrato é uma generalidade, porém posta pelo capital e que compreende a diversidade. É um universal que se manifesta concretamente de modo particular, isto é, nas múltiplas formas concretas de trabalho (FAUSTO, 1983). O trabalho é assim reduzido a um único trabalho, o social, geral. Mas essa redução não é apenas fisiológica, mero gasto de energia humana, conforme diz Ricardo (p. 197).

Já mencionei, a respeito desse assunto, o estudo de R. Fausto (1983). Pois bem. Ensina-nos esse autor, seguindo as pegadas de Marx, é bom que se diga, que o gasto de músculos, nervos, etc. não constitui o trabalho abstrato, porque the falta o momento da singularidade. A abstração é um processo essencialmente social, por meio do qual o trabalho é reduzido a um dado tempo, o tempo de trabalho socialmente necessário, tempo esse que é a medida do trabalho. Sem essa redução do trabalho a trabalho socialmente necessário, o trabalho abstrato não se constitui. Tampouco determina-se o valor, cuja substância é o trabalho social. É isso que Marx diz acontecer todos os dias, por meio de um mecanismo redutor em que os diferentes trabalhos, ao serem reduzidos a um determinado tempo, tornam-se abstratos. Claro é que há nisso uma inversão. Mas é justamente essa inversão que permite compreender por que o trabalho social é abstrato e o trabalho concreto particular, bem como por que o trabalho particular só pode se realizar enquanto manifestação concreta do trabalho social.

Prossigamos, no entanto, com Ricardo no exame da classe trabalhadora. Ela engloba, além dos trabalhadores produtivos, os trabalhadores improdutivos (p.197), entre os quais se incluem os assalariados do setor de serviços (p.197). Compõem-na ainda, os assalariados rurais, 
os precarizados e os membros do exército de reserva. São excluídos dela o pequeno proprietário, os diretores e gerentes de empresas, gestores do capital, e que por isso mesmo, conquanto assalariados pertencem à classe dominante (p.200-201).

É essa a síntese que faz da classe trabalhadora hoje, do novo proletariado, mais heterogêneo, mais complexificado e mais fragmentado, que contempla o proletariado urbano, o proletariado rural e o subproletariado (p.201). Conclui, portanto, pela diferenciação da classe trabalhadora, clivada em trabalho interno e trabalho externo, trabalho qualificado e trabalho desqualificado, trabalho estável e trabalho precário, trabalho em tempo integral e trabalho em tempo parcial, trabalho fixo e trabalho temporário, trabalho com registro em carteira e trabalho informal, trabalho com direitos e trabalho sem direitos, homens e mulheres, jovens e velhos, imigrantes e nacionais, brancos e negros (p.191, 199, 201-207).

A classe trabalhadora, acentua Ricardo, tornou-se “ (...) mais qualificada em vários setores, como na siderurgia, onde houve uma relativa intelectualização do trabalho, mas desqualificou-se e precarizouse em diversos ramos, como na indústria automobilística, onde o ferramenteiro não tem mais a mesma importância que antes, sem falar na revolução dos inspetores de qualidade, gráficos, mineiros, portuários, trabalhadores da construção naval, etc. Criou-se, de um lado, em escala minoritária, o trabalhador "polivalente e multifuncional", capaz de operar máquinas de controle numérico e mesmo converter-se no que Marx chamou, nos Grundrisse, de supervisor e regulador do processo produtivo. De outro lado, tem-se uma massa precarizada, sem qualificação, que hoje é atingida pelo desemprego estrutural" (p.191).

Aprofunda desse modo a idéia de heterogeneidade e fragmentação do proletariado, idéia essa esboçada desde 1995, no seu Adeus ao proletariado?. Naquele livro assim como no atual, é refém da vida imediata, que é tomada em si e por si, sem a necessária mediação com a realidade maior na qual se insere e a qual exprime empiricamente. Perde de vista o caráter social das classes, das suas lutas e dos seus pressupostos: o trabalho e a produção. O que é um lapso para um "marxiano marxista" de linhagem luckacsiana, pois desconsidera um preceito elementar da dialética, a precedência do social sobre a vida imediata, cotidiana (LUCKÁCS, 1989; MARCUSE, 1969; HELLER, 1991; KOSIK, 1976). 
Reduz, em consequiência disso, o conceito de classes ao imediato, empírico. Por isso fala em heterogeneidade, complexidade e fragmentação da classe trabalhadora, características essas típicas da vida cotidiana (NETO, 1996). Todavia, o que é próprio desse nível fenomênico e aparente da realidade é o indivíduo e não as classes sociais. Apesar de real, a fragmentação é uma aparência, que, enquanto tal, é negadora da unidade. Se ela realmente acontecesse, as classes implodiriam, assim como o trabalho, seu pressuposto. $O$ trabalho não se restringe ao trabalho concreto. Mesmo o trabalho concreto supõe a cooperação, a troca e a divisão do trabalho. Assim sendo, ele realiza-se como partícula do trabalho social. É esse trabalho social que assume determinadas formas concretas. Ele é um universal que se faz concreto, uma unidade do diverso, não para Ricardo, evidentemente, para quem parece haver somente a diversidade.

O elemento fisiológico é, pois, apenas um pressuposto do trabatho abstrato, cuja generalidade só se efetiva com a indústria moderna, a qual muito mudou, impulsionada pela dinâmica das forças produtivas, que amplia a divisão do trabalho e a troca, ambas igualmente pressupostos da referida generalidade. Mais do que isso. Ao longo desse processo, a indústria generaliza-se. Ela que no passado recente invadiu a agricultura e os serviços, ganha novo alento com a automação microeletrônica em curso, revolucionando a sua maneira de produzir e simplificando ainda mais o trabalho que, por causa disso, se universaliza mais, de forma a perder as especialidades que lhe restam. A especialização pertence ao passado, a universalização ao presente e, por certo, ao futuro. Querer voltar à especialização, o que não é o caso de Ricardo. mas de tantos outros, é querer perpetuar o "idiotismo da profissão", cuja morte fora anunciada pela revolução industrial do século XVIII.

É esse trabalhador que está condenado a desaparecer. No seu lugar comparece o trabalhador universal, que vem sendo cunhado, com propriedade, embora inconscientemente, de polivalente. Com propriedade, porque o nome exprime a universalidade do trabalho, a qual pressupõe a sua maior simplificação, imposta pela nova tecnologia. É esta que subverte o processo de trabalho, de modo a extirpar a especialização e a fragmentação do trabalho. Essa é a tendência natural. Pois só assim o capital pode realizar o seu desígnio primordial, qual seja, o de 
reduzir o tempo de trabalho necessário, com vistas à sua valorização. Se esta encontra barreiras, elas não decorrem de uma crise do trabalho, como pensa o Ricardo de Adeus ao trabalho? (1995), nem do subconsumo, conforme quer o Ricardo de Os sentidos do trabalho (1999), mas da sobreacumulação, que comprime a taxa de lucro. O que é uma maneira de evidenciar a vigência da lei do valor. Tal vigência depende, por sua vez, da vigência do trabalho social. $O$ valor é objetivação desse trabalho, esse universal de que os muitos trabalhos concretos são formas particulares de existência e sem o qual não vigiriam o valor e a sua lei. Pelo menos é o que mostra a experiência cotidiana. Segundo esta, a diversidade concreta do trabalho não suprime a sua universalidade. Caso suprimisse, não se teria como equiparar entre si os seus diferentes produtos: as mercadorias. A troca seria então inviabilizada. No entanto, ela é viabilizada. Isso porque as várias formas concretas de trabalho, responsáveis pela criação das distintas mercadorias, são reduzidas a algo puramente social, a saber: o trabalho abstrato. Essa redução consiste na abolição da sua efetiva desigualdade que, conforme se viu, acontece diariamente, a todo instante. Numa sociedade igual a nossa, em que o trabalho é medido pelo tempo, esse fato é inevitável. E o trabalho que se mede desse jeito não aparece como trabalho de diferentes sujeitos. Em vez disso, as pessoas que trabalham aparecem como órgãos do trabalho social. Trabalho esse em que qualquer indivíduo médio pode ingressar e realizá-lo sob uma de suas inúmeras formas concretas, desde que se insira na divisão social do trabalho. Prova-o hoje mais do que nunca - a sua mobilidade, mediante a qual se pode passar facilmente de uma modalidade a outra de trabalho e da qual a polivalência é uma das suas manifestações empíricas. Há muito o trabalho compreende um duplo aspecto: geral e particular, trabalho social que se particulariza em trabalho concreto. Ele não perdeu a sua generalidade. Ainda a conserva. Apesar de se realizar diversamente e de a indústria estar se reestruturando, tal generalidade permanece posta por esta. A automação microeletrônica, ao contrário do que se comumente pensa, a confirma e amplia. O que, a bem da verdade, é um progresso. Logo, o trabalho ainda é uma unidade que compreende a diversidade ou, para repetir o já dito, é um universal que se faz concreto (MARX, 1983; GIANNOTTI, 1975). 
É este o motivo pelo qual não se pode endossar a idéia de que o trabalho se fragmentou. Tal idéia nega a universalidade do trabalho. Se essa universalidade tivesse realmente desaparecido, a troca ficaria inviabilizada e nós estaríamos frente a uma nova sociabilidade, o que não ocorre. Corrobora isso o elevado grau de expansão alcançado pela troca, a qual invade até mesmo os lugares mais distantes do mundo. A sociabilidade que nela se define, por meio da forma valor, é capitalista. Se a sociabilidade persiste capitalista, é porque a sociedade na qual ela vige não se auto-superou nem se decompôs. Bem ao inverso disso, constitui uma totalidade, que igualmente ao trabalho, seu fundamento material, compreende a diversidade. Também ela é uma unidade do diverso; é, por assim dizer, uma síntese de muitas determinações; síntese que é feita continuamente pelo capital, esse sujeito automático que a domina e que põe e repõe, nesse processo de síntese, as efetivas condições de sua existência (MARX, 1974; GIANNOTTI, 1966; 1975).

Tem mais. A universalidade do trabalho abstrato resulta, bem se sabe, da simplificação que lhe é imposta pela máquina. À medida que esta evolui, e com ela o sistema de máquinas, o trabalho tende a uma maior universalização. É o que se assiste nos dias que correm, com a inovação tecnológica, mas também, e principalmente, com a industrialização generalizada, ambas em curso. Daí porque não tem sentido falar em crise do trabalho ou fragmentação do trabalho. Se isso fosse verdade, a sociabilidade estaria beirando o desabamento, com a ruína do seu fundamento material: o trabalho. A verdade é que nem este nem aquela estão chegando ao fim. Muito pelo contrário, ambos encontram-se em franco processo de universalização. E não há porque se lamentar. Mesmo no capitalismo, essa universalização é um progresso. Ela revela o avanço das forças produtivas e justamente por isso dissolve relações arcaicas, de um lado, e, de outro, indica a possibilidade de abolição da divisão do trabalho, seguramente que não sob o capitalismo, pois tal abolição só poderá se dar noutra sociedade, em que a sociabilidade for diretamente social.

Resta dizer que se a fragmentação do trabalho viesse a acontecer, o trabalho implodiria e, com ele, o valor e tudo o mais. Há evidências de que nada disso sucede. Para o que nos interessa aqui, basta explicitar a permanência da sociabilidade capitalista, que se define na troca, por meio da forma valor - que é produto do trabalho abstrato. $\mathrm{O}$ trabalho não perdeu a 
sua generalidade. Ele é, com efeito, abstrato e concreto. Por meio de sua forma concreta, produz valor de uso, e por meio de sua forma abstrata, produz valor. Ricardo confunde esse duplo aspecto do trabalho. Reduz o trabalho abstrato ao trabalho concreto, o que, diga-se, não é novidade, visto que tantos outros cometem esse equívoco, dentre eles, Gorz (1982), Offe (1989), Habermas (1985; 1987), seus interlocutores prediletos. No tocante a Ricardo, cabe assinalar que não é o trabalho abstrato que produz automóvel, computador, etc. Automóvel, computador, etc. são valores de uso. $\mathrm{O}$ trabalho que produz valor de uso é o trabalho concreto. O trabalho abstrato produz valor. Explicita-se, assim, a confusão entre trabalho abstrato e trabalho concreto. Penso que isso ocorre por terem se tornado, cada qual a seu modo, reféns da vida imediata.

Em Ricardo há outra confusão, já assinalada, a referente ao trabalho vivo e ao trabalho abstrato. Acontece que, como se viu, nem todo trabalho vivo é trabalho abstrato. Uma coisa a mais. Conquanto o trabalho abstrato seja substância e medida do valor, não é em torno dele que se edifica a sociedade capitalista e sim do trabalho assalariado. É este trabalho determinado que é determinante da sociedade burguesa (MARX, 1983; GIANNOTTI, 1966). É o trabalho assalariado que "impregna a sociedade em toda a sua amplitude e converte-se em sua base" (MARX, 1971), estendendo-se nos tempos atuais (acrescento eu: JFB), mais do que nunca, à sua superfície inteira.

Mais uma vez, discordo de Ricardo, que ao defender a centralidade do trabalho, associa-a ao trabalho abstrato (p.213, 214 e 219). A despeito de esta forma de trabalho ser a única capaz de dar vida ao trabalho morto acumulado nas diversas atividades dos vários setores da economia; a despeito de ela estar adquirindo uma maior amplitude, enlaçando um crescente número de trabalhos concretos, graças principalmente ao mecanismo de universalização resultante da inovação tecnológica, ao qual se submetem, ela não fundamenta a sociedade capitalista (TAUILE, 1999; SCHIMITZ, 1988; LOJKINE, 1990; KUMAR, 1997; BRAVERMAN, 1977; OLIVEIRA, 2000).

Essa tecnologia põe a organização científica desse processo num patamar mais elevado. A produção automatiza-se. O trabalho universaliza-se. À medida que isso sucede, o processo imediato de trabalho é negado: o trabalho deixa de ser o elemento que o domina e lhe dá 
forma. Ele aparece apenas como órgão consciente de um sistema automático ao qual se subordina e do qual não é mais do que um elo, cuja unidade reside na maquinaria, essa forma de materialização do capital diante da qual a capacidade de trabalho individual praticamente desaparece (MARX, 1971; GIANNOTTI, 1966; TAUILE, 1999). Permanece, contudo, a primazia do trabalho vivo sob a forma assalariada, pressuposto do trabalho abstrato, impulsionador da acumulação e de sua expressão empírica, o trabalho concreto, produtor dos valores de uso necessários à vida humana.

Convém observar que o processo social de trabalho não é uniforme. Concretamente, coexistem processos imediatos de trabalhos automatizados, semi-automatizados, não automatizados, uns mais outros menos dependentes do elemento subjetivo, muitos dos quais assentados em bases técnicas equivalentes à da manufatura, moderna $\mathrm{e}$ não moderna, outros, porém, assentados em base técnica moderníssima. Mesmo entre as indústrias, há indústrias de fluxo contínuo (de propriedade) e indústrias de fluxo descontínuo (de forma). As primeiras, das quais a petroquímica é um expoente, são em geral automatizadas. As segundas, como a metalurgia, não são automatizadas. A produção que nelas se realiza é descontínua. Em que pese o fato de a informatização aproximar esses dois tipos de indústrias, é inegável o descompasso entre elas e dentro de cada uma delas, mormente nas indústrias de fluxo descontínuo. Isso sem falar do enorme número de pequenas unidades produtivas ou do trabalho externo às fábricas, ambas espalhadas pelo mundo afora e portadoras de base técnica e força de trabalho variadas. Fosse diferente, as modernas técnicas de gestão da força de trabalho não mais vigorariam, racionalizadoras que são do tempo de trabalho e dos movimentos do trabalhador, além de motivadoras deste (SILVA, 2001).

Essa variedade aparece nos demais setores da economia nos quais também é grande a disparidade tecnológica e da força de trabalho. Haja vista os serviços e a agricultura. Ambos encontram-se industrializados e numa fase relativamente avançada, que incrementa a universalização do trabalho, responsável pela sua mobilidade por entre as diversas atividades rurais e urbanas, e ratificadora do seu caráter abstrato e, por isso mesmo, unitário (BERTERO, 1997, 1995; BRAVERMAN, 1977; OLIVEIRA, 1978, 2000). O trabalho rural e os ser- 
viços não estão à margem do trabalho social. Ao revés, são suas partículas concretas. Por mais diferenciadas que sejam essas partículas, elas não existem sem o trabalho social, ao qual pertencem e o qual exprimem. A diversidade não consiste em trabalho em tempo parcial, temporário, trabalho de homens, de mulheres, de negros, de brancos, de jovens, de velhos etc. Ela diz respeito ao ofício, à especificidade profissional, isto é, à forma particular do trabalho. É essa especialidade que tende a desaparecer com a simplificação e a consequiente universalização do trabalho, senão graças à Deus, graças à história, que caminha para frente e não para trás, como querem alguns. Malgrado o fato de a universalização do trabalho fazer-se sob os auspícios do capital, e em seu proveito, ela é um avanço. Felizmente, está-se bem longe do operário sintético de Proudhon.

Pode-se dizer que o mesmo sucede com as classes sociais. Enquanto relações, as classes são universais concretos, ou seja, unidade do diverso. O proletariado não é homogêneo. Ele compreende desde um simples operário ou um faxineiro de uma empresa, até um gerente, um técnico, etc. O gerente é proletário, sim. Ele é um assalariado a serviço do capital, cujo trabalho contribui à sua valorização. É membro do trabalho coletivo, essa máquina produtiva humana da qual participam igualmente técnicos, engenheiros, operários, etc., e em que uns trabalham mais com as mãos, outros com a cabeça e assim por diante.

A burguesia, em nada difere disso, no que diz respeito à sua diferença endógena, bem entendido. Encontra-se no seu interior uma burguesia industrial, uma burguesia comercial, uma burguesia financeira, uma burguesia agrária. Cada uma dessas frações é diferenciada internamente pelo montante de seus respectivos capitais, fato que dá origem a uma pequena burguesia, média burguesia, grande ou alta burguesia, as quais também se diferenciam internamente.

Tampouco os proprietários fundiários fogem dessa diferenciação. Contudo, diferenciação interna não significa, de maneira alguma, fragmentação. Porquanto a diferenciação se verifica no interior de uma unidade, sem a qual não há classes. Elas implodiriam. Aí sim, teríamos que fazer coro com os que decretam o fim das classes. A fragmentação proletária assinalada pelo Ricardo é empírica, fenomênica.

Contudo, uma coisa é certa: as classes não existem sem o trabaIho. Mas qual trabalho? Obviamente, pelo exposto, o social, no caso do 
proletariado, que inclui o operariado, o gerente, o técnico, etc., bem como o médico, o professor, o ator, etc., desde que assalariados em uma empresa prestadora de serviços. É isso que lhes dá identidade de classes. A identidade se dá por meio do trabalho social, abstrato, do qual são simples órgãos. Ocorre que esse trabalho só pode se realizar concretamente. A bem da verdade, trabalho social ou abstrato e trabalho concreto são indissociáveis. O primeiro produz não só valor como maisvalia, imprescindível à valorização do capital, os quais se materializam nos valores de uso criados pelo trabalho concreto e indispensáveis à vida humana. O trabalho tem, com efeito, um duplo aspecto: concreto e abstrato. É a um só tempo as duas coisas. O trabalho concreto é a forma de manifestação do trabalho abstrato, que se realiza empiricamente de modo diverso, motivo pelo qual é um universal concreto. O pressuposto disso é o assalariamento. $\mathrm{O}$ assalariado tem uma maior abrangência que o proletariado, uma vez que engloba trabalho improdutivo. Assalariado e proletário não se equiivalem, meu caro Ricardo. Pense num empregado doméstico, num funcionário público, num ministro de Estado, num pequeno produtor que trabalha como assalariado de si mesmo, os exemplos são muitos. Todos eles são assalariados, mas não são proletários, nos termos de Marx, de O Capital e do Capítulo VI (inédito), note bem. Digo isso, porque considera a sua definição "marxiana e marxista" (p.196). Tanto é assim que redefine o seu conceito inicial, passando a conceber a classe trabalhadora como conjunto de trabalhadores produtivos (grifos do autor). Razão pela qual ela "não diz respeito somente aos trabalhadores manuais diretos, senão que incorpora (hoje) a totalidade do trabalho social, a totalidade do trabalhador coletivo que vende sua força de trabalho em troca de salário". "A classe trabalhadora é hoje centralmente composta pelo conjunto dos trabalhadores produtivos... É este o núcleo central do proletariado moderno" (p.197). E o trabalho que produz mais-valia, valorizando o capital, é o trabalho abstrato - o qual, já se sabe, é visto por ele, Ricardo, como "dispêndio de energia física e intelectual" (p.197).

Entretanto, devo concordar com Ricardo, quando diz que o trabalho não acabou. Pois sem ele não haveria como suprir as necessidades humanas, assim como não haveria capital. Tanto essas necessidades continuam sendo supridas - abstraindo-se, é claro, a miséria e a 
fome que assolam o mundo - como há capital. Ressalve-se que, embora se incorpore em coisas tangíveis, o capital não é coisa, mas relação social, de classes. Sem classes, não há produção material, nem capital, muito menos a sociedade na qual ele impera, a capitalista.

Também no que tange a persistência das classes e do capitalismo Ricardo tem razão. Aproveito esse momento de minha exposição para tocar em outro ponto: o da superação da lógica capitalista. Ricardo considera que "a produção deve ser prioritariamente voltada para os 'valores de uso' e não para os 'valores de troca"'; que essa produção tenha por base "o 'tempo disponível' e não o 'tempo excedente", isso para que o capital não mais controle o tempo livre das pessoas (p.193, 194); que "o ponto de partida para instaurar (essa) nova lógica societal é desenvolver uma crítica contemporânea e profunda à (des)socialização da humanidade ..." (p.194).

Penso que o ponto de partida para a superação da sociabilidade capitalista é a evolução forças produtivas e não a crítica. A dinâmica das forças produtivas cria as condições materiais necessárias à referida superação. Nunca tais condições estiveram tão maduras como estão agora. Elas nos conduzem para uma situação inédita, na qual poderá se dar a abolição da divisão do trabalho. A produção tornar-se-á, então, diretamente social. Com isso, desaparecerão o valor, a troca e logicamente, a sociabilidade indireta, bem como o fetichismo delas resultantes, mistificador das relações sociais. Se é correta a idéia de que a ciência é necessária por não haver coincidência entre aparência e essência, é provável que ela se torne supérflua. Porém, enquanto a produção persistir mercantil, isso não sucederá. $O$ trabalho não será posto desde o início como trabalho social. Será, obrigatoriamente, mediado pela troca. Somente por meio desta correlata da divisão do trabalho é que poderá ser posto como trabalho social (ROSDOLSKY, 1979)². Antes que me acusem de mecanicista, é bom deixar claro que não estou supondo que a sociedade capitalista se negará tecnicamente, sem a mediação de lutas de classes. Mesmo sendo verdade que existe uma "destruição criadora" no capitalismo, é improvável que ele se autosupere automati-

\footnotetext{
2 Vale mencionar que Rosdolsky é um organizador dos Grundrisse, o que quer dizer que as idéias não são suas mas de Marx.

: A lógica do capital não é só destrutiva.
} 
camente, isto é, sem intervenção política que o ponha em xeque. Eis porque é preciso ter clareza quanto às forças sociais em jogo. A precisão conceitual não é uma exigência apenas teórica, senão também prática. Teoria e prática são inseparáveis. Formam uma unidade.

Com a generalização da troca em escala mundial, que atinge cada vez mais um número maior de atividades, as relações mercantis esparramam-se como uma mancha de óleo, invadindo os vários recantos do planeta, mesmo os mais longínquos e aparentemente desconectados da divisão do trabalho, cuja ampliação segue de perto a evolução da troca. Definidora que é da sociabilidade capitalista, a troca, ao se generalizar, acarreta a universalização da mencionada sociabilidade, ao mesmo tempo que ratifica a vigência da forma valor, sua reguladora e regente da dinâmica capitalista que preside a sociedade. Já aqui os argumentos de Habermas, que tanto atormentam Ricardo, são problematizados, pois, a menos que se queira ser arbitrário com o social, não há como negar a veracidade desses fatos.

Mas não é só o mercado de produtos que se universaliza. Além dele, universalizam-se os mercados de trabalho e de capital, sobretudo este último, o qual é acompanhado pelo acirramento da concorrência, agravado pela contração da produção capitalista, que dá margem à especulação financeira (CHESNAIS, 1997; MANDEL, 1990). A produção que se internacionalizara no imediato pós-guerra, reajusta-se em âmbito mundial, repercutindo na divisão do trabalho em nível internacional (HOBSBAWM, 1995). A isso tudo liga-se o advento de um novo padrão de acumulação, sob a liderança do capital financeiro, ao que tudo indica hegemônico, e centrado em indústrias emergentes que, em geral, operam em escala mundial nos ramos de informática, telecomunicação, comunicação e cultural. Esse novo padrão dá à acumulação um caráter mundial: ela mundializa-se, na expressão de Chesnais (1997: 1998). A sua implantação nos anos 80 se deve aos impasses nos quais desembocou o padrão anterior, centrado nas indústrias de bens de capital e de bens de consumo durável, associados ao capital bancário. Os impasses assinalados que levaram à substituição deste padrão, na verdade decorrem da retração da produção, que redundou numa superprodução, não de mercadorias mas de capital, materializado em meios de produção, que passam a operar em ociosidade, provocando, de uma parte, a queda 
da taxa de lucro e, de outra, a exclusão de pessoas do processo produtivo. Se isso é indicativo de crise, e é, tal crise é crise de acumulação, que se vê bloqueada pelo excesso de capital em relação à massa de maisvalia, que se mostra incapaz de por em movimento todo o montante de capital acumulado. É essa a causa da crise e não o subconsumo, que é resultante dela. Pensar o inverso, é pensar que a meta imediata do capitalismo é o valor de uso, quando de fato o que ele visa é a sua incessante expansão mediante a contínua valorização do capital (GOGOY, 1977; MATICH, 1980; BELLUZZO, 1980). Note-se que a acumulação permanece como mola propulsora da dinâmica social, o que, por seu lado, evidencia a vigência da lei do valor como sua regente. A propósito da persistência dessa lei, nada melhor que a crise para evidenciá-la, provocada que é pela queda da taxa de lucro (MANDEL, 1990).

Ainda estamos diante de uma sociedade capitalista. Ela, aliás, não só continua capitalista como apresenta, pela primeira vez em sua história, uma industrialização generalizada, estendendo-se ao campo e aos serviços, impondo-lhes a sua racionalidade (MANDEL, 1983; BRAVERMAN, 1977; OLIVEIRA, 1978; LOJKINE, 1990). A agricultura industrializa-se a partir do momento em que passa a incorporar a base técnica de origem industrial: num primeiro momento, mecanizando e quimificando o seu processo produtivo, mediante a adoção de tratores e seus acessórios, além de plantadeiras, colheitadeiras e outros equipamentos, no caso da mecanização; e mediante a adoção de produtos químicos, a saber: adubos, venenos, corretivos, etc., no caso da quimificação. Posteriormente, ao lado da racionalização e do aprimoramento das práticas agrícolas modernas, tem-se a introdução de novas variedades de sementes e espécies, em geral precoces e melhor adaptadas às condições endoclimáticas; e, mais recentemente, a utilização do computador em atividades agropecuárias. Acompanha esse processo a mudança de suas linhas produtivas, que são redirecionadas para a indústria. Altera, dessa forma, o seu modo de produzir, que se industriali$\mathrm{za}$, as suas linhas de produção, que se especializam e se diversificam, assim como as suas relações de trabalho, destruindo antigas formas, em regra não assalariadas ou não plenamente assalariadas, e substituindoas por assalariados, cujo montante cresce, mas também preservando formas não assalariadas de trabalho, ainda que muitas vezes modifica- 
das, porém sempre com nítidos reflexos na estrutura social, cuja composição assimila-se cada vez mais à urbana.

Associam-se a essas mudanças, a desruralização da população e a urbanização do campo. No primeiro caso, verifica-se, além do esvaziamento populacional e do conseqüente densenraizamento das pessoas do meio rural - constatáveis, respectivamente, no decréscimo relativo e absoluto do contingente daquelas pessoas e na maior mobilidade delas - o estabelecimento no seu interior da sociabilidade capitalista, cujos nexos, sabe-se, estabelecem-se no mercado, em que as pessoas são indiferentes umas às outras, contando apenas e tão somente as coisas de que são portadoras. No segundo caso, tem-se uma profunda modificação no modo de produzir, com a industrialização da agricultura, e nas maneiras de armazenar, comercializar, transportar, consumir, comunicar-se, relacionar-se e, logo, de viver.

Isso sugere que a indústria impôs o seu modo de ser ao campo, estando ambos submetidos a uma única e mesma dinâmica, a capitalista avançada (MANDEL, 1983; BELL, 1977; OLIVEIRA, 1978; GUIMARÃES, 1979; MULLER, 1985; BRAND, 1997). Digo campo, porque a pecuária e a avicultura passam por mudanças similares às ressaltadas. Além disso, o campo - que já não é mais campo, mas uma extensão da cidade - tem diversificado as suas atividades, das quais cito apenas algumas: turismo, hotelaria, pesca, flores, frutas, hortaliças, legumes, etc. A agricultura converte-se dessa maneira em ramo da indústria, com a qual forma uma nova unidade.

A despeito da sua não corporeidade, é crescente a execução de serviços em moldes empresariais. Assinalar isso não significa desconsiderar os serviços prestados de outra maneira, cujos exemplos maiores são indubitavelmente os serviços públicos e domésticos. Uma coisa, porém, é um jardineiro que presta serviços de jardinagem em minha casa e ao qual remunero com renda. Outra coisa é o serviço de jardinagem realizado em minha casa, por um empregado de uma empresa prestadora de tal serviço. Aqui o trabalhador é um assalariado, cujo trabalho realiza-se sob o mando do capital, a quem deve valorizar, o que não acontece na situação anterior. Mas isso não quer dizer que o serviçal seja um conta própria, autônomo, informal. Ele pode ser um assalariado ou capitalista dele mesmo. Neste caso, mesmo que pobre, não é 
proletário. Quando muito, pode ser semi-proletário, e isso se assalariar temporariamente noutras lides. Proletário é, por exemplo, um professor de uma escola privada, ou uma empregada de uma lavanderia, ou faxineiro de um hotel. Em todos esses casos as relações de trabalho são mediadas pelo capital, se bem que nem sempre de maneira igual. Tais mediações são extensivas a outras modalidades de serviços. Pensem no serviço médico, do advogado, do escritor, do jornalista, do cantor, do ator, do publicitário, do mecânico, do funileiro, do transportador de carga, da prostituta, etc. Esses serviços certamente inserem-se diversamente na produção social. Mas não é isso que se quer ressaltar e sim as particularidades existentes em cada um deles. Tome-se o trabalho médico, a título de ilustração. Um médico pode ser um pequeno capitalista, enquanto proprietário de um consultório ou de uma pequena clínica; assalariado, mas não proletário, como funcionário de uma instituição pública de saúde; proletário, enquanto assalariado de uma clínica ou de um hospital privados. Normalmente, ele é tudo isso, senão quase tudo. Mesmo que não seja isso tudo, de um jeito ou de outro, ele se insere na divisão do trabalho, da qual as distintas formas do seu trabalho são expressões concretas. Isso quer dizer que é um trabalhador da sociedade, na qual e para a qual trabalha de diferentes maneiras. E o faz, com frequiência, sob a batuta do capital, para cuja valorização contribui.

Por último, lembro que os serviços também se industrializaram. Primeiramente, pela adoção de veículos e máquinas manuais. Depois, pela adoção de máquinas elétricas, seguidas de máquinas eletrônicas e por fim da informática, ocasião em que se tem uma mudança profunda no seu âmbito, com o computador desempregando um número considerável de pessoas. Haja vista os bancos, os escritórios, etc. Ao longo desse processo, grande parte dos serviços passa a realizar-se empresarialmente. O trabalho que neles se efetua entra para o rol do trabalho social, esse organismo sem o qual o capital não se valoriza e mais e mais o trabalho concreto não se realiza (BRAVERMAN, 1977; GIANNOTTI, 1983). Verifica-se a socialização dos serviços, ao mesmo tempo que eles se transformam num campo de investimento de capital. A não ser para os apologistas, acumulação e serviços não são incompatíveis, razão por que não se justifica a associação entre a sua expansão e o advento da sociedade pós-industrial (BELL, 1977). Tão improcedente quanto o ar- 
gumento em prol da sociedade pós-industrial é o de que os serviços constituem formas superiores ou libertárias de trabalho. Ao contrário, eles se submetem, em escala crescente, aos ditames do capital e não raramente a uma exploração abusiva do trabalho que neles se exerce. Confirmam isso, não raro, os pequenos serviços, que normalmente funcionam como autênticos refúgios de desempregados, os quais engrossam as fileiras do exército de reserva, por obra da revolução tecnológica em andamento, mas também, e principalmente, por obra da crise econômica que assola o capitalismo há quase três décadas.

Resta o trabalho a domicílio, cuja expansão, de acordo com Ricardo, acontecera em função da desconcentração da produção e do crescimento de pequenas e médias unidades produtivas (p.114). Assinala que não se trata de uma "reintrodução pelo capital de formas pretéritas de trabalho", com as quais mantêm vínculos diretos, subordinando-as diretamente (p.115). Assinala ainda, que essas formas de trabalho possibilitam "uma economia de força de trabalho e de capital" (p.114). Mas que malgrado isso, elas "encontram-se ainda limitadas", se bem que contribuem para a "conformação mais heterogênea e mais fragmentada da "classe que vive do trabalho" (p.114-115).

Penso ter demonstrado a imprecisão do conceito de "classe que vive do trabalho". Quanto à sua suposta fragmentação, ressalto que ela é fenomênica, aparente e que não suprime a unidade da classe. Não é que a classe não se diferencie empiricamente: a diferenciação interna é inerente à classe. Todavia, a diferenciação interna a que me refiro é distinta da apontada por Ricardo. E não só à classe trabalhadora, mas à toda a classe social. Nenhuma classe social é homogênea. Basta ver a burguesia, cuja diferenciação interna já foi assinalada por mim.

Algo semelhante ocorre com o trabalhador à domicílio moderno, que compreende uma imensa variedade de formas de trabalho, geralmente executadas em pequenos empreendimentos industriais, agropecuários, comerciais ou de outras espécies de serviços, e cujos nexos com a produção social nem sempre são visíveis. É certo que em determinados casos os vínculos são claros. Cito, a propósito, os casos da Benetton e da Nike, mencionados por Ricardo, e que parecem revelar isso. A eles pode-se acrescentar outros casos, tais como o da Nestlè, da Cica, da Souza Cruz, da Sadia, dos supermercados, dos atacadistas, das 
grandes casas comerciais e cooperativas, etc., empresas essas para as quais as unidades domiciliares freqüentemente operam sob encomenda, e das quais extraem produtos e matérias-primas a preços comprimidos que thes possibilitam elevadas taxas de lucro.

Em outros casos, porém, como se disse, os vínculos não são claros. É o que acontece com a confecção, fiação, tecelagem, tapeçaria, fabricação de rendas, sapatos, produtos de metal e engenharia (SCHIMITZ, 1988).

Quer os vínculos com a produção social sejam claros ou não, o trabalho a domicílio subsume-se no capital, o qual se ancora na exploração de mão-de-obra barata, de homens adultos mas também de mulheres e crianças, submetidos à longas jornadas de trabalho e cujos salários quase sempre estão aquém dos da força de trabalho normal. Isso me leva a supor que tal mão-de-obra compõe o mercado de trabalho, bem como o mercado interno. A sua produção, por sua vez, compõe o mercado de produtos. Não se configura de modo algum como produtora de autoconsumo ou algo a ela assemelhado. O mais provável é que produz mercadorias por meio de mercadorias. O produto do seu trabalho é valor de troca, trabalho geral objetivado. Ela é, pois, produtora da sociedade, que nela e para ela produz. Afasta-se, dessa maneira, a hipótese de autonomia. As formas de trabalho por meio das quais se realiza são, em regra, formas do capital, as quais agem como reservatórios de gente, que nelas se refugia, mormente as pessoas que perderam os seus empregos, mas que, não obstante isso, não implicam necessariamente a expropriação total do trabalhador. Eis por que, embora explorado, não raramente descapitalizado, empobrecido e em vias de proletarização, não se confunde com o proletário. Ainda que precariamente e muitas vezes apenas formal, é proprietário de meios de produção, os quais comumente revestem a forma de capital. Além do mais, enquanto produtor da sociedade, submete-se à taxa média de lucro, da qual depende a valorização do seu pequeno capital.

E isso, caro Ricardo, é extensivo ao produtor rural e aos serviços. A particularidade do primeiro deles radica na renda da terra. Quando, contudo, não se apropria da mais-valia, não valoriza o capital nem a terra, quer dizer, não realiza nem o seu capital nem a renda da terra. Transforma-se, então, num proprietário formal de capital e da terra, 
num simples proprietário jurídico. O que não é raro, sobretudo no meio rural. Visto desse ângulo, é pouco provável que a luta pela terra travada pelos sem-terra seja progressista. Não só. Uma vez assentado, o trabalhador deixa de ser proletário. Certo é que muitos assentados não conseguem extrair de seu lote de terra o suficiente para o seu sustento e o de seus familiares. Neste caso, quando não abandonam a terra, são forçados a se assalariarem temporariamente noutras lides. Assumem, em consequiência, a condição de semi-proletários, muito comum entre os pequenos produtores rurais.

A particularidade dos serviços é que eles próprios é que são mercantilizados, uma vez que não se corporificam em objetos tangíveis, e que nem todo serviço é produtivo. Mas daí supor que os serviços estão à margem da produção social tem uma distância enorme.

Disse linhas atrás que o trabalho a domicílio pertence à divisão social do trabalho. Disse ainda que ele se utiliza de mão-de-obra barata, ao que acresço agora: farta e disciplinada (FERGUS, s/d), o que não significa que ele seja incompatível com a tecnologia moderna. Mesmo o trabalho a domicílio recriado na retaguarda da indústria, pela revolução industrial do século XVIII, valia-se da máquina. A máquina não lhe era incompatível e sim o sistema de máquinas. Entretanto, naquela época, a máquina era manual, ao passo que hoje ela é elétrica ou eletrônica. A microeletrônica vem sendo usada pelo trabalho externo, em especial nas unidades produtoras subcontratadas pelas grandes empresas ou a elas filiadas (FERGUS, s/d; SCHIMITZ, 1988). Outras, porém, apresentam uma base técnica limitada. Em ambos os casos, contudo, tem-se uma economia das condições de produção. O trabalho a domicílio é um meio de reduzir o custo produtivo, porque comprime os gastos salariais e com meios de produção; redução essa que se faz com vistas a elevar a rentabilidade do capital às expensas, é claro, do trabalhador, que, além de superexplorado, arca com os riscos e as perdas (FERGUS, s/d). Nada disso, porém, é inédito. Inédito é fato de as grandes empresas ou seus conglomerados valerem-se desses expedientes para fazer face à tendência à queda da taxa de lucro e, ao mesmo tempo, diminuir os conflitos trabalhistas .

Conforme se nota, está-se bem longe da suposta fragmentação da classe trabalhadora. O processo em curso aponta na direção oposta 
a isso, ou seja, ele caminha para o alargamento e o fortalecimento do trabalho coletivo. Ricardo admite isso, só que, incongruentemente, advoga a idéia de fragmentação da classe trabalhadora.

Viu-se que a sociedade permanece capitalista; que ela generaliza a industrialização; a qual, por seu turno, tende a universalizar o trabalho, fato que reforça e amplia a sua socialização, com o crescente assalariamento e a inclusão de parte dos serviços e do trabalho rural no rol do trabalho produtivo.

Mais do que isso: dado que a agricultura e os serviços são organizados em moldes industriais, é possível entender parte do trabalho assalariado que neles se realiza como assemelhado ao operário. Quem diria, esse trabalho que aparecera antes na fábrica e mais tarde chegara ao campo, estaria agora presente nos serviços. Se bem que não em todos os serviços, mas tão somente em alguns deles, que ademais de mercantilizados e executados por intermédio de empresas, acham-se freqüentemente modificados pela crescente perda do seu caráter manual.

Eis que estamos novamente diante dos trabalhos operário e proletário. Sabemos que eles não se confundem, nem com os assalariados, menos ainda com o que Ricardo chama de "classe que vive do trabaIho". O proletariado é mais abrangente que o operariado, e menos abrangente que os assalariados, cujo contingente inclui trabalhadores improdutivos, e menos abrangente que "os que vivem do trabalho", que abarcam assalariados e não assalariados.

Se a agricultura e grande parte dos serviços estão realmente organizados em moldes empresariais, com uma base técnica equivalente à indústria moderna, não é nenhum esquerdismo barato conceber o trabalho assalariado que neles se realiza como similar ao operário. Certo é que isso não acontece por acaso. Ao contrário, supõe uma dada socialização do trabalho. Só que o trabalho social não é composto apenas pelo trabalho operário. Além deste, ele compreende outros trabalhos concretos, descle que inseridos na produção social, a saber: os trabalhos (assalariado, frise-se) de gerentes, engenheiros, técnicos, médicos, advogados, professores, cantores, atores, aviadores, aeromoças, porteiros, camareiros, faxineiros, serventes, enfim, de ampla gama de trabalhos concretos, normalmente subsumidos no capital, ao qual rendem um excedente. Para que isso se dê, não é preciso operar manual- 
mente nem gerar coisas tangíveis. Basta ser membro do trabalho coletivo, simples partícula sua. É isso que os "une". As várias modalidades de trabalho que executam não são mais que formas de manifestação dessa unidade, que é o trabalho social ou abstrato. Não fosse assim, ele não seria um universal-concreto. O pertencimento à essa coletividade, além de uní-los, os potencializa e identifica.

Mas esse pertencer não é algo fixo, senão mutável. Posto que é esse trabalho social que gera valor, a contínua mutabilidade das formas concretas de trabalho os potencializa e esteriliza seguidamente. Ao mesmo tempo que esteriliza certos trabalhos concretos, tornando-os improdutivos, o capital, em seu constante movimento de reposição, incorpora outros trabalhos, igualmente concretos, novos ou que anteriormente não atuavam sob sua égide e que, portanto, não eram produtivos. Ele incorpora, mas também exclui, num movimento de síntese, os membros do trabalho social: os primeiros, sabe-se, são produtivos; os segundos, improdutivos. Convém mencionar que o trabalho que, em determinada circunstância gera valor, não tem valor. Tem valor o seu pressuposto, a força de trabalho que por sua vez deve passar pelo mercado para assumir a forma mercantil e assim poder encarnar essa abstração social que é o valor.

As classes giram em torno do valor. Melhor dizendo, é o seu processo de autovalorização que determina a situação de classes das pessoas. Ser burguês ou proletário é um atributo do capital. Como se sabe, interessa-me examinar o proletariado hoje. Nos começos dessa resenha, expus o conceito de proletário. Acrescento agora que à medida que a produção especificamente capitalista se aprimora e se expande, mais indiferenciado o trabalho se torna. Não que o trabalho concreto se homogeneize. Longe disso. O que se assiste é a sua maior heterogeneidade. Sucede que o trabalho heterogêneo não tem autonomia, expressão que é do trabalho abstrato. E isso não somente porque cresce o trabalho assalariado, pressuposto do aumento da troca. Senão também, principalmente com isso, incrementam-se a cooperação, a divisão social do trabalho e, por conseguinte, a socialização da produção. Ora, tal socialização não é mais que o enlaçamento por esse organismo social, que é o trabalho abstrato, de mais trabalhos concretos, os quais perdem a sua independência. 
Ser membro do trabalho social já não é mais um privilégio do operário fabril. Digo operário fabril, porque a classe operária não é formada só por ele. Ela compreende, além dele - e não importa se o trabalho que efetua é interno ou externo à fábrica ou à outra empresa a que se vincula -, assalariados dos transportes, das comunicações, dos armazéns, das minas, dos estaleiros, da construção civil, de alguns outros serviços mercantis cuja básica técnica é semelhante à industrial, e parcela considerável dos assalariados do campo. O fato de haver dentro do operariado quem trabalhe em empresas estatais não altera a sua situação de classe. $O$ trabalho que nelas se realiza não é menos produtivo que o trabalho realizado em empresas privadas. Os seus executores são componentes do trabalho social. Além do que, ambas empresas acumulam capital. Se, em dadas circunstâncias, a empresa estatal não consegue fazê-lo satisfatoriamente, certamente não é por causa do trabalho que nela se efetua e sim do modo pelo qual se subsume no processo de produção social, que lhe impede a apropriação de um fatia maior da mais-valia social.

Não se conclui do que foi dito que todo trabalho assalariado produtivo é operário. Conquanto produtivo, nem sempre o assalariado prestador de serviço por meio de uma empresa privada é operário. É, isto sim, no mais das vezes, proletário. O mesmo sucede com o gerente, o administrador, o contador e demais pessoas do escritório de empresas capitalistas, o engenheiro, o técnico, todos eles assalariados produtivos. Mas que, a despeito disso, também não são operários: menos pelo saber e salários diferenciados que ostentam e recebem, e mais por serem prepostos do capital, uma espécie por assim dizer de seus funcionários especiais que embora produtivos, pela posição que possuem na hierarquia empresarial, participam, a serviço do capital, do mecanismo de exploração do trabalho alheio. Continuam, entretanto, assalariados e subsumidos no capital, cuja racionalidade personificam. Revelam, por esse motivo, certa ambiguiidade. Talvez por isso lhe seja cabível a designação de aristocracia proletária.

Faz-se mister lembrar que as relações sociais que dão origem a essas formas de trabalho são móveis. Elas sofrem os efeitos da dinâmica do capital. À medida que este se reproduz, elas tendem a mudar. Essa mudança reflete na composição social, que é de classes. Não é à toa que estas estão em permanente mutação. Refazem-se continuamente. Ao 
reporem o capital por meio do trabalho social, elas repõem a si mesmas. O movimento de reposição do capital é, entre outras coisas, o movimento de reposição das classes. Movimento esse que, curiosamente, tem a atrás de si as referidas classes, de cuja práxis depende e que, ao mesmo tempo que o reitera, reitera a si próprias, nele se refazendo. Sempre, contudo, modificados, processo e classes, e nunca tal e qual existiam antes. Mais: se só existem na luta, como suponho, esse seu fazer e refazer adquire um caráter político. Luta que travam essencialmente num nível mais amplo e profundo que o nível imediato e superficial da realidade social, no qual o trabalho se configura na sua concretude e o operariado e o proletariado apresentam-se, em regra, atomizados. No entanto, não é nesse nível imediato e superficial que as classes se definem e sim naquele nível mais geral e profundo. É nesse mesmo nível que se dão as inclusões e as exclusões, bem como as esterilizações e potencializações, antes mencionadas, as quais, cumpre notar, tendem a ocorrer mais pronunciadamente em épocas de crise.

Vê-se quão desprovida de sentido é a suposta fragmentação das classes. Até porque, se isso realmente tivesse se verificado, não haveria classes nem sociedade, pois ambas teriam implodido. Essa é, aliás, a tese defendida por adeptos dos movimentos sociais. Apesar de poderem se apresentar empiricamente desse modo ou a ele parecido, as classes e seus personificadores, os indivíduos, são postos pelo capital. Tendem, por essa razão, a ocupar posições sociais por ele indicadas, vindo a compor uma unidade, contraditória é verdade, mas uma unidade, no caso das classes, sem a qual elas não existem. Os mesmos indivíduos compõem camadas ou estratos, que se superpõem umas às outras, de maneira a constituir uma hierarquia social.

É certo que há desdobramentos, mediante os quais as classes se particularizam concretamente. São, entretanto, as suas formas de aparição concretas, que nem sempre condizem com as daquele nível mais geral em que são repostas. Enquanto nesse nível mais geral impera a unidade do diverso, no outro nível impera apenas a diferença. Em ambos, todavia, há identidade entre os personagens. Só que num deles a identidade é dada pelo emprego, tipo de trabalho, salário, etc., em síntese, por estes e mais elementos que habitam a superfície social, em contraposição ao trabalho abstrato, submerso nas profundezas da vida 
social e que dá identidade ao proletariado. Não que esses níveis sejam desconexos. Há mediações entre eles, as quais precisam ser desvendadas, sob pena de se comprometer a compreensão e a explicação do social. É o que parece suceder com a análise de Ricardo, quando identifica proletário, assalariados em geral e "classe que vive do trabalho".

Procurei deixar claro que nem todos que vivem do trabalho são assalariados e muito menos proletários. Se proletário é o assalariado cujo trabalho valoriza o capital e tão logo se torne desnecessário a sua valorização é posto na rua, ele inclui os trabalhadores produtivos da ativa e a massa de desempregados e subempregados que integram as fileiras do exército de reserva. Isso mostra a atualidade do apelo: "proletários de todos os países, uní-vos".

\section{Referências Bibliográficas}

Antunes. R. Adcus ao trabalho? São Paulo: Cortez, 1995.

Os sentidos do trabalho. São Paulo: Boitempo Editorial, 1999.

BEL.., D. O advento da sociedade pós-industrial. São Paulo: Cultrix, 1977.

Beıl.uzzo, L. G. Valor e Capitalismo. São Paulo: Brasiliense, 1980.

BERTERo, J. F. Nem tudo se fragmentou: notas sobre um discurso de F.H. Cardoso. Estudos de Sociologia, Araraquara, n.2, p.39-58, 1997.

O embate entre o capital e o trabalho: as greves no meio agrário paulista. Perspectivas, São Paulo, v.17/18, p.167-182, 1994/1995.

Brand, V. C. Do colono ao bóia-fria: transformações na agricultura e constituição do mercado de trabalho na Alto Sorocabana de Assis. Estudos Cebrap, São Paulo, n 19. p 37-91, jan/mar 1977.

Bravirman. H. Trabalho e Capital Monopolista. Rio de Janeiro: Zahar, 1977.

Chesnais. F. A emergência de um regime de acumulação financeira. São Paulo: Hucitec, 1997. (Estudos Marxistas 3)

Crise da Ásia ou do Capitalismo? Entrevista concedida à Antônio Martins. Tempo e Presença, v.20, n.301, p.40-44, set/out, 1998. 
Fausto, R. Marx. Lógica e Política. São Paulo: Editora Brasiliense, 1983. t.1. Lógica e Política. São Paulo: Editora Brasiliense. 1987. t.2.

Giannotti, J. A. Contra Althusser. Exercícios de Filosofia. São Paulo: Cebrap Brasiliense, 1975.

Formas da sociabilidade capitalista. Trabalho e Reflexão. São Paulo: Brasiliense, 1983.

. Origens da Dialética do Trabalho. São Paulo: Difel. 1966.

Gogoy, M. Teoria da Acumulação Capitalista. Porto: Publicações Escorpião, 1977.

Gorz, A. Adeus ao proletariado. Rio de Janeiro: Forense, 1982.

GUIMARÃES, A. P. A crise agrária. Rio de Janeiro: Paz e Terra. 1979.

Habermas. J. A nova intransparência. Novos Estudos CEBRAP, São Paulo, n.l8. p.103-114. 1987.

Ensayos políticos. Barcelona: Ediciones Peninsula. 1985.

Hell.er, A . Sociologia de la vida cotidiana. Barcelona: Ediciones Península, 1991.

Hobsbawn, E. A Era dos Extremos. O breve século XX. (1914-1991). São Paulo: Companhia das Letras, 1995.

Kosik, K. Dialética do concreto. Rio de Janeiro: Paz e Terra, 1976.

Kumar, K. Da sociedade pós-industrial à pós-moderna. Rio de Janeiro: Zahar. 1997.

Lonkine, J. A classe operária em mutações. Belo Horizonte: Oficina de Livros. 1990.

Lukács, G. História e consciência de classe. Rio de Janeiro: Elfos, 1989.

Mandel, E. O capitalismo tardio. São Paulo: Abril Cultural, 1983.

A crise do capital. São Paulo: Ensaio, 1990.

Marcuse, H. Razão e Revolução. Rio de Janeiro: Saga, 1969.

MARx, K. Elementos fundamentales para la critica de la economia política (borrador). 1857-1858. México: Siglo Veintiuno Editores, 1971.

Introdução à contribuição a crítica da economia política.In:

Para a crítica da economia política. São Paulo: Abril Cultural, 1974 (Os Pensadores). 
Marx, K. Miséria da Filosofïa. Porto: Publicações Escorpião, 1974.

O Capital. São Paulo: Ciências Humanas, 1978. (Inédito).

O Capital. São Paulo: Abril Cultural, 1984. v.1, t.1, 2. (Os

Economistas)

Manifesto Comunista. Rio de Janeiro: Zahar, 1967.

Matıch. P. Crítica de la teoria económica contemporánea. México: Ediciones Era, 1980.

Mul l.ek, G. A velha senhora agrária e seus novos balangandãs. Novos Estudos CEBRAP, São Paulo, n.11, p.2- 9, jan., 1985.

Neto, J. P. Cotidiano: conhecimento e crítica. São Paulo: Cortez, 1996.

OFF, C. Trabalho como categoria sociológica fundamental? In: Trabalho

e Socicdude. Rio de Janeiro: Tempo Brasileiro, 1989.

Ol.iveıra, F. Classes sociais em mudança e a luta pelo socialismo. São Paulo: Fundação Perseu Abramo, 2000.

O clo perdido. Classe e identidade de classe. São Paulo:

Brasiliense. 1987.

O terciário e a divisão social do trabalho. Novos Estudos CEBRAP, São Paulo, n.24, p.137-168, 1978.

Rosborsky, R. Genesis y estructura de "El Capital" de Marx. México: Siglo Veintiuno. 1979.

Schimir\%, H. Automação microeletrônica e trabalho: a experiência internacional. In: Hucitec, 1988. (Orgs.) Automação, competividade e trabalho. São Paulo:

Sil.VA, F. L. G. Gestĩo da força de trabalho e capital: do paradigma taylorista-fordista de produção em massa ao sistema de produção em massa flexível. 2001. Tese (Doutorado em Sociologia) - Faculdade de Ciências e Letras, UNESP, Araraquara, 2001.

TAUil.E, J. R. As transformações do capitalismo contemporâneo e sua natureza na análise de Marx. Revista de Economia Política, v.19, n.1, p.158-181, jan./mar., 1999. 